\title{
PENGARUH KEADILAN ORGANISASIONAL TERHADAP KEPUASAN KERJA KARYAWAN BANK NAGARI CABANG UTAMA PADANG
}

\author{
Tiara Annisa, Riri Mayliza \\ Sekolah Tinggi Ilmu Ekonomi "KBP" \\ ririmayliza@akbpstie.ac.id \\ tiaraanisa2994@gmail.com
}

\begin{abstract}
This study aims to obtain empirical evidence of the influence of organizational justice as measured by procedural justice, distributive justice and interactional justice to employee job satisfaction. In this study, a sample of 123 employees of Bank Nagari Branch of Padang selected by using purposive sampling method. The analysis method used is multiple regression and t-statistic test. Based on the results of hypothesis testing that has been done found that procedural justice and distributive justice have a significant effect on job satisfaction of employees of Bank Nagari Main Branch Padang, while interactional justice has no significant effect on employees of Bank Nagari Main Branch Padang
\end{abstract}

Keyword : Procedural justice, distributive justice, and interactional justice

\section{PENDAHULUAN}

Dalam beberapa tahun terakhir perkembangan dunia perbankan di Indonesia terus mengalami peningkatan. Perkembangan dunia perbankan ditandai dengan begitu banyaknya bank konvensional yang terus tumbuh dan berkembang untuk bersaing meraih pasar nasabah diseluruh wilayah di tanah air. Salah satu bank konvensional yang terus berkembang adalah bank daerah. Diantara sekian banyak bank daerah, Bank Nagari Sumatera Barat adalah salah satu yang terdepan. Dari semenjak berdirinya hingga saat ini bank kebanggaan masyarakat Sumatera Barat tersebut terus mengalami kemajuan yang signifikan mulai dari jumlah nasabah, pencapaian kinerja keuangan dan pelayanan hingga luas wilayah operasional.

Tingginya persaingan bisnis dalam dunia perbankan saat in mendorong manajemen bank memberikan tanggung jawab yang besar bagi seluruh karyawannya untuk terus memajukan atau mengembangkan Bank Nagari Sumatera Barat. Tanggung jawab yang tinggi mendorong karyawan Bank Nagari memiliki rutinitas yang tinggi dalam bekerja seta dihadapkan pada tekanan yang besar dalam bekerja. Untuk mengimbangi besarnya tanggung jawab dan tekanan dalam bekerja pihak manajemen memberikan nilai kompensasi yang tinggi bagi karyawan. Pemberian kompensasi yang tinggi kepada karyawan dimaksudkan untuk menciptakan kepuasan kerja bagi karyawan. 
Menurut Robbins dan Timothy (2012) kepuasan kerja menunjukan adanya kesesuaian antara keinginan atau harapan yang diharapkan dengan realitas yang dirasakan dalam bekerja. Kepuasan kerja akan menciptakan kenyamanan dalam bekerja, Kenyamanan yang dirasakan akan mendorong munculnya komitmen karyawan untuk menjaga eksistensi bank dalam jangka panjang. Menurut Rizzo et al (1997) kepuasan kerja yang dirasakan karyawan dapat diamati dari kepuasan yang dirasakan karyawan pada gaji, kepuasan pada rekan rekan kerja, kepuasan pada penyelia dan kepuasan yang dirasakan karyawan pada pekerjaan itu sendiri.

Menurut Gibson et al (2009) kepuasan kerja yang dirasakan karyawan tidak terbentuk dengan sendirinya akan tetapi dipengaruhi oleh sejumlah variabel. Salah satu variabel yang mempengaruhi terbentuknya kepuasan kerja adalah keadilan dalam organisasi.

Menurut Gibson et al (2009) keadilan dalam organisasi menunjukan adanya kesesuaian yang dirasakan karyawan dalam bekerja antara kewajban dengan reward yang diterima karyawan dalam bekerja. Keadilan dalam organisasi akan menciptakan persaingan yang sehat dalam bekerja. Keadilan yang dirasakan karyawan dalam organisasi dapat dikelompokan menjadi tiga dimensi yaitu keadilan distributif, keadilan prosedural dan keadilan interaksional.

Kedilan distributif menunjukan keadilan yang dirasakan karyawan dalam mendistribusikan kompensasi financial atau pun non financial. Semakin tinggi tingkat keadilan secara distributif akan meningkatkan kepuasan kerja yang dirasakan karyawan Keadilan procedural merupakan level kesesuaian antara tingkatan prosedur yang harus dilalui seluruh anggota organisasi untuk menduduki sebuah posisi didalam organisasi, sedangkan keadilan interaksional merupakan nilai kesesuaian yang dirasakan pegawai untuk diperlakukan sama didalam pergaulan yang melibatkan seluruh elemen organisasi.

Menurut Wibowo (2010) keadilan prosedural menunjukan nilai keadilan yang dirasakan karyawan secara prosedural, khususnya proses yang dijalani setiap individu untuk mendapatkan sebuah jabatan. Keadilan prosedural yang dilakukan secara benar oleh pimpinan akan mendorong terciptanya persaingan yang sehat dan dinamis sehingga menguntungkan organisasi. Dimensi keadilan organisasi yang ketiga adalah keadilan interaksional yaitu menunjukan nilai keadilan yang berhubungan dengan interaksi yang terjadi antara karyawan dengan sesama karyawan atau karyawan dengan atasan. Ketika tidak terjadi ketimpangan dalam proses interaksi, dimana setiap individu dapat berinteraksi atau berkomunikasi dengan baik dengan seluruh anggota organisasi, khususnya sesama karyawan, pimpinan hingga masyarakat yang berada di sekitar organisasi.

\section{Tujuan Penelitian}

Sesuai dengan perumusan masalah, tujuan dilaksanakannya penelitian ini adalah:

1. Menganalisis dan membuktikan secara empiris pengaruh keadilan distirbutif terhadap kepuasan karyawan Bank Nagari Cabang Utama Padang.

2. Menganalisis dan membuktikan secara empiris pengaruh keadilan prosedural terhadap kepuasan karyawan Bank Nagari Cabang Utama Padang. 
3. Menganalisis dan membuktikan secara empiris pengaruh keadilan interaksional terhadap kepuasan karyawan Bank Nagari Cabang Utama Padang.

\section{LANDASAN TEORI \\ Kepuasan Kerja}

Davis dan Newton (2004:44) mendefinisikan bahwa kepuasan kerja merupakan keadaan emosional yang menyenangkan atau tidak menyenangkan dimana para pegawai memandang pekerjaannya. Berarti kepuasan kerja merupakan hal-hal yang dapat menyenangkan atau perasaan positif yang merupakan akibat dari penghargaan terhadap pekerjaan seseorang. Tingkah laku keryawan yang malas menimbulkan masalah bagi perusahaan berupa tingkat absensi yang tinggi, keterlambatan kerja dan pelanggaran disiplin yang lainnya, tingkah laku karyawan yang puas lebih menguntungkan bagi perusahaan.

\section{Faktor-Faktor Kepuasan Kerja}

Faktor-faktor yang menentukan kepuasan kerja tidak hanya sekedar melakukan pekerjaan, akan tetapi terkait juga dengan aspek lain seperti interaksi dengan rekan sekerja, atasan, mengikuti aturan-aturan, dan lingkungan kerja tertentu yang sering kali tidak memadai. Hal di atas menunjukkan bahwa kepuasan kerja seseorang di pengaruhi oleh banyak faktor, tidak hanya gaji, tetapi terkait dengan pekerjaan itu sendiri. Mangkunegara (2013:120) menyatakan bahwa ada dua faktor yang mempengaruhi kepuasan kerja, yaitu faktor pegawai dan faktor pekerjaan.

\section{Keadilan Organisasional}

Menurut Robbins dan Timothy (2012:143) keadilan organisasi pertama sekali berkembang melalui teori relative deprivation oleh Stouffer pada tahun empat puluhan. Pada dasarnya keadilan organisasi menyatakan bahwa reaksi seseorang terhadap suatu hasil (outcome) akan tergantung pada bagaimana perbandingan hasil yang dihasilkan oleh individu dengan hasil orang lain.

\section{Keadilan Distributif}

Robbins dan Timothy (2012: 122) mendefinisikan kompensasi sebagai nilai balas jasa yang diterima pegawai atau karyawan dalam bekerja. Didalam mengukur kompensasi maka digunakan keadilan distributif (distributive justice). Keadilan distributif berhubungan dengan distribusi balas jasa yang diterima individu yang bekerja dalam sebuah organisasi, keadilan distributif berhubungan dengan besaran gaji yang diterima dengan dasar utama waktu bekerja, tingkat kesulitan, jam kerja hingga adanya risiko kerja.

\section{Keadilan Prosedural}

Keadilan procedural adalah keadilan yang dirasakan dari proses yang digunakan untuk menentukan distribusi imbalan (Robbins dan Timothy, 2012). Pada penelitian ini keadilan procedural yang diukur yaitu untuk mengetahui sejauhmana keadilan yang dirasakan pegawai dalam memperoleh distribusi imbalan. Greenberg (1990) dalam Gibson et al (2009) menyatakan bahwa keadilan prosedural berhubungan dengan kepuasan kerja, mengingat keadilan procedural berhubungan dengan pelaksanaan prosedur bagi pegawai untuk mendapatkan kompensasi. Ketika pegawai merasakan keadilan dalam 
memperoleh kompensasi diyakini kepuasan kerja dalam diri pegawai akan terwujud. Keadilan procedural juga berhubungan dengan perlakuan yang diterima pegawai pada saat berusaha memperoleh kompensasi. Proses tersebut dilakukan dengan keseriusan dan pengorbanan waktu dan tenaga dalam bekerja. Semakin tinggi keadilan procedural yang dirasakan pegawai akan mendorong meningkatnya nilai kepuasan kerja yang dirasakan pegawai.

\section{Keadilan Interaksional}

Menurut Gibson et al (2009) keadilan interaksional menunjukan sejauhmana seorang pegawai untuk diberlakukan dengan penuh rasa hormat dan sesuai dengan martabatnya. Keadilan interaksiona berhubungan dengan perasaan yang dimiliki oleh pegawai dalam proses interaksi didalam organisasi yang melibatkan pegawai dengan sesama pegawai, atau pun pegawai dengan atasan. Ketika pegawai merasakan kenyamanan lewat adanya sikap saling hormat menghormati dan harga menghargai maka akan mendorong kenyamanan dalam bekerja, sehingga secara langsung akan memperoleh pencapaian dalam bekerja sekaligus mendorong rasa puas yang dirasakan pegawai dalam bekerja.

\section{Tinjauan Penelitian Terdahulu}

\section{Pengaruh Keadilan Distributif Terhadap Kepuasan Kerja}

Gibson et al (2009:148) mengungkapkan bahwa keadilan distributif menunjukan kesesuaian distribusi hak dan kewajiban didalam sebuah organisasi. Salah satu bentuk keadilan distributive adalah keadilan didalam perolehan kompenasi dalam bentuk gahi, insentif, bonus atau pun tunjangan. Semakin baik distribusi keadilan yang dirasakan seorang pegawai dalam bekerja akan mendorong muncul kepuasan kerja.

Penelitian yang dilakukan oleh Stephen dan Schappe (1998) yang berjudul understanding employee job satisfaction: the importance of procedural and distributive justice. Didalam penelitian ini digunakan tiga dimensi keadilan organisasiional yang terdiri dari keadilan distributive, keadilan procedural dan keadilan intraksional. Model analisis yang digunakan untuk membuktikan kebenaran hipotesis adalah dengan menggunakan model regresi berganda dan pengujian t-statistik.

\section{Pengaruh Keadilan Prosedural Terhadap Kepuasan Kerja}

Robbins dan Timothy (2012:219) mengungkapkan bahwa keadilan procedural menunjukan keadilan proses atau tahapan yang dilalui oleh seluruh anggota organisasi untuk mendapatkan pengakuan diri oleh atasan dalam bentuk promosi, pujian, penghargaan atau pun bonus yang muncul akibat adanya keberhasilan dalam bekerja. Semakin tinggi keadilan procedural yang dirasakan oleh seluruh anggota organisasi akan menciptakan nilai persaingan yang sehat, akibatnya kenyamanan dan kepuasan dalam bekerja akan meningkat, sehingga dapat disimpulkan bahwa keadilan procedural berpengaruh positif terhadap kepuasan kerja yang dirasakan pegawai dalam sebuah organisasi.

Krisnayanti dan Riana (2015) mengungkapkan bahwa keadilan organisasional yang diukur dengan keadilan procedural berpengaruh terhadap kepuasan kerja yang dirasakan pegawai,

Hasil penelitin Kenneth et al (2007) mengungkapkan bahwa terjadi pengaruh langsung antara keadilan procedural terhadap kepuasan kerja pegawai. 
Hasil yang diperoleh tersebut menunjukan bahwa semakin tinggi tingkat keadilan procedural yang dirasakan pegawai mendorong menguatnya kepuasan kerja yang dirasakan pegawai. Keadaan tersebut menunjukan bahwa harapan pegawai untuk mendapatkan proses atau prosedur yang sama dalam bekerja, seperti sama sama mendapatkan tanggung jawab dan beban kerja yang sama, mendapatkan perhatian yang sama dari pimpinan, proses kenaikan pangkat yang sama hingga perlakuan yang sama dalam bekerja mampu mendorong perasaan nyaman dan puas dalam diri pengawai yang bekerja.

Pengaruh Keadilan Interaksional Terhadap Kepuasan Kerja

Gibson et al (2009:149) mendefinisikan keadilan interaksional sebagai keadilan yang dirasakan seluruh anggota organisasi yang berhubungan dengan interaksi pegawai dengan sesama pegawai atau pun interaksi yang terjadi antara pegawai dengan atasan. Semakin baik tingkat hubungan, dimana hubungan yang terjadi tidak dilihat atau dikelompokan berdasarkan strata jabatan, melainkan lebih menonjolkan nilai kekeluargaan maka kenyamanan dalam bekerja akan terbentuk sehingga mendorong menguatnya kepuasan dalam bekerja melalui keberhasilan atau prestasi yang diperoleh oleh pegawai. Jadi dapat disimpulkan bahwa keadilan inteaksional berpengaruh positif terhadap kepuasan kerja.

Kristanto (2013) mengungkapkan bahwa kebebasan dan keharmonisan yang diraskaan pegawai dalam berinteraksi didalam organisasi, telah menciptakan soliditas didalam bekerja sama serta rasa kekeluargaan yang tinggi dan mendorong terbentuknya kenyamanan dan iklim organisasi yang mendorong pencapaian prestasi kerja yang lebih baik, akibatnya kepuasan dan kenyamanan dalam bekerja akan terbentuk.

Hipotesis

Sesuai dengan teori dan sejumlah hasil penelitian terdahulu maka diajukan beberapa hipotesis yang akan dibuktikan dalam penelitian ini yaitu:

$\mathrm{H}_{1}$ Keadilan distributif berpengaruh positif terhadap kepuasan kerja karyawan Bank Nagari Sumatera Barat

$\mathrm{H}_{2}$ Keadilan prosedura berpengaruh positif terhadap kepuasan kerja karyawan Bank Nagari Sumatera Barat

$\mathrm{H}_{3}$ Keadilan interaksional berpengaruh positif terhadap kepuasan kerja karyawan Bank Nagari Sumatera Barat

\section{METODOLOGI PENELITIAN}

Jenis Penelitian

Penelitian yang dilakukan saat ini dapat digolongkan sebagai penelitian deskriptif kuantitatif. Secara deskriptif penelitian ini menceritakan berbagai perilaku karyawan Bank Nagari Cabang Utama Padang yang terpilih sebagai sampel, sedangkan secara kuantitatif penelitian ini juga memiliki hipotesis yang dapat dibuktikan dengan bantuan alat uji statistik yaitu melalui analisis model regresi linear berganda.

Populasi

Menurut Margono (2010:17) populasi adalah seluruh data yang menjadi perhatian kita dalam suatu ruang lingkup dan waktu yang kita tentukan. Dalam 
penelitian ini populasinya adalah seluruh karyawan Bank Nagari Cabang Utama Padang yang berjumlah 178 orang.

\section{Sampel}

Menurut Sekaran (2013:85) sampel merupakan bagian dari populasi yang dianggap mewakili. Didalam penelitian ini yang menjadi sampel adalah beberapa orang pegawai Bank Nagari Cabang Utama Padang. Untuk menentukan ukuran atau jumlah sampel yang digunakan maka digunakan rumus Slovin yang dapat dicari dengan formula sebagai berikut:

$$
\begin{aligned}
& n=\frac{178}{1+178(0.05)^{2}} \\
& n=\frac{178}{1+178(0.0025)} \\
& n=\frac{178}{1.445}=123,18
\end{aligned}
$$

Sesuai dengan perhitungan rumus Slovin maka jumlah atau ukuran sampel yang digunakan dalam penelitian ini adalah 123 orang. Agar peneliti mendapatkan ukuran sampel sebanyak 123 orang responden maka digunakan metode purposive sampling. Menurut Sekaran (2010) purposive sampling adalah metode pengambilan sampel yang didasarkan pada kriteria khusus yang terdapat dalam populasi. Kriteria yang digunakan meliputi:

1. Individu yang terdaftar sebagai karyawan tetap Bank Nagari Sumatera Barat.

2. Karyawan yang ditempatkan pada Bank Nagari Cabang Utama Padang.

\section{Definisi dan Operasional Variabel Variable Dependen \\ Kepuasan Kerja (Y)}

Davis dan Newton (2004:44) menyatakan bahwa kepuasan kerja merupakan keadaan emosional yang menyenangkan atau tidak menyenangkan dimana para pegawai memandang pekerjaannya. Untuk mengukur kepuasan kerja maka digunakan indikator yang diadopsi dari Celluci, Anthony J dan David L.De Vries (1978) dalam Mas'ud (2004:185) yaitu sebagai berikut:

a) Kepuasan dengan gaji

b) Kepuasan dengan promosi

c) Kepuasan dengan rekan kerja

d) Kepuasan dengan penyelia

e) Kepuasan dengan pekerjaan itu sendiri

\section{Variabel Independen} meliputi:

Secara umum variabel independen yang digunakan didalam penelitian ini

\section{Keadilan Distributif}

Menurut Tjahjono (2007) keadilan distributif yang menunjukan sejauhmana kompensasi yang diterima pegawai atau karyawan sebuah perusahaan dirasakan adil didalam proses pendistribusiannya. Didalam mengukur keadilan distributif maka digunakan indikator dari Tang dan Safied Baldwin (1996) dalam Mas'ud (2004:211) dengan menggunaan indikator sebagai berikut, 
a. Keadilan atas imbalan yang diterima sesuai dengan prestasi yang dicapai

b. Keadilan terhadap imbalan yang diterima sesuai dengan kemampuan

c. penghargaan yang diterima sesuai dengan prestasi yang dicapai

\section{Keadilan Prosedural}

Keadilan procedural adalah keadilan yang dirasakan dari proses yang digunakan untuk menentukan distribusi imbalan (Robbins dan Timothy, 2012:312). Didalam mengukur keadilan procedural maka digunakan indikator yang diadopsi dari Tang Ling Ping dan Linda T dan Linda J Baldwin (1996) yaitu

a) Keadilan dalam penilaian prestasi kerja yang dilakukan oleh pimpinan secaraperiodik,

b) Keadilan dalam penilaian prestasi kerja yang dilakukan oleh supervisor

c) Keadilan dalam penilaian prestasi yang dilakukan oleh diri pribadi.

\section{Keadilan Interaksional}

Keadilan interaksional merupakan penilaian yang diberikan individu tentang sejauhmana karyawan diperlakukan dengan baik serta penuh rasa hormat dan adil antara satu karyawan dengan karyawan yang lain. Didalam mengukur keadilan interaksional maka diadopsi indikator dari Colquitt (2001) yaitu
a) Kesopanan,
b) Bermartabat,
c) Hormat,
d) Kejujuran,
e) Tepat waktu dan spesifik.

\section{HASIL DAN PEMBAHASAN}

\section{Uji Instrumen Penelitian}

\section{Hasil Pengujian Validitas}

\section{Kepuasan Kerja}

Kepuasan kerja merupakan variabel pertama yang digunakan didalam penelitian. Didalam mengukur kepuasan kerja maka digunakan 20 item pertanyaan. Berdasarkan hasil pengujian validitas yang telah dilakuakn diperoleh ringkasan hasil terlihat pada Tabel 1 dibawah ini:

\section{Tabel 1}

Validitas Variabel Kepuasan Kerja

\begin{tabular}{|l|c|c|c|}
\hline \multicolumn{1}{|c|}{ Item Pertanyaan } & $\begin{array}{c}\text { Koefisien Factor } \\
\text { Loading }\end{array}$ & Standar & Kesimpulan \\
\hline Kepuasan_1 & 0.784 & $\geq 0,40$ & Valid \\
\hline Kepuasan_2 & 0.879 & $\geq 0,40$ & Valid \\
\hline Kepuasan_3 & 0.717 & $\geq 0,40$ & Valid \\
\hline Kepuasan_4 & 0.696 & $\geq 0,40$ & Valid \\
\hline Kepuasan_5 & 0.723 & $\geq 0,40$ & Valid \\
\hline Kepuasan_6 & 0.606 & $\geq 0,40$ & Valid \\
\hline Kepuasan_7 & 0.590 & $\geq 0,40$ & Valid \\
\hline Kepuasan_8 & 0.525 & $\geq 0,40$ & Valid \\
\hline Kepuasan_10 & 0.607 & $\geq 0,40$ & Valid \\
\hline Kepuasan_12 & 0.578 & $\geq 0,40$ & Valid \\
\hline Kepuasan_16 & 0.843 & $\geq 0,40$ & Valid \\
\hline Kepuasan_17 & 0.823 &
\end{tabular}

Sumber: Olahan Data Sekunder: 2017 
Pada Tabel terlihat bahwa 12 item pertanyaan yang digunakan didalam mengukur variabel kepuasan kerja valid. Masing masing item pertanyaan yang valid memiliki nilai factor loading diatas atau sama dengan 0,40 sedangkan 6 item pertanyaan lainnya di eliminasi karena mengalami ambigu atau tidak memenuhi syarat pengujian.

\section{Keadilan Distributif}

Keadilan distributif merupakan salah satu dimensi yang berhubungan dengan keadilan organisasional. Didalam mengukur keadilan distributif maka digunakan 5 item pertanyaan Sesuai dengan hasil pengujian validitas yang telah dilakukan diperoleh ringkasan hasil terlihat pada Tabel 2 dibawah ini:

Tabel 2

Hasil Pengujian Validitas Variabel Keadilan Distributif

\begin{tabular}{|l|c|c|c|}
\hline $\begin{array}{c}\text { Item } \\
\text { Pertanyaan }\end{array}$ & Koefisien Factor Loading & Standar & Kesimpulan \\
\hline Distributif_1 & 0,778 & $\geq 0,40$ & Valid \\
\hline Distributif_2 & 0,830 & $\geq 0,40$ & Valid \\
\hline Distributif_3 & 0,862 & $\geq 0,40$ & Valid \\
\hline
\end{tabular}

Sumber: Olahan Data Sekunder: 2017

Pada Tabel terlihat bahwa tiga item pertanyaan yang digunakan didalam mengukur variabel keadilan distributif valid. Masing masing item pertanyaan yang valid telah memiliki satu compenen dengan koefisien factor loading diatas atau sama dengan 0,40 didalam tahapan pengujian dua item pernyataan di eliminasi dari tahapan pengolahan data karena tidak memenuhi syarat pengujian.

\section{Keadilan Prosedural}

Berdasarkan hasil pengujian validitas yang telah dilakukan diperoleh ringkasan hasil terlihat pada Tabel 3 dibawah ini:

Tabel 3

Hasil Validitas Variabel Keadilan Distributif

\begin{tabular}{|c|c|c|c|}
\hline $\begin{array}{c}\text { Item } \\
\text { Pertanyaan }\end{array}$ & Koefisien Factor loading & Standar & Kesimpulan \\
\hline Prosedural_1 & 0,758 & $\geq 0,40$ & Valid \\
\hline Prosedural_2 & 0,834 & $\geq 0,40$ & Valid \\
\hline Prosedural_3 & 0,864 & $\geq 0,40$ & Valid \\
\hline Prosedural_4 & 0,516 & $\geq 0,40$ & Valid \\
\hline
\end{tabular}

Sumber: Olahan Data Sekunder: 2017

Pada Tabel terlihat bahwa empat item pertanyaan yang digunakan didalam mengukur keadilan distributif valid, masing masing item pertanyaan yang valid memiliki satu component memiliki factor loading diatas atau sama dengan 0,40 sedangkan satu item pertanyaan lagi dengan kode prosedural_5 dan prosedural_6 di eliminasi karena mengalami ambigu oleh sebab itu seluruh item pertanyaan yang valid dapat terus digunakan kedalam tahapan pengolahan data lebih lanjut.

\section{Keadilan Intraksional}

Sesuai dengan hasil pengujian validitas yang telah dilakukan diperoleh ringkasan hasil seperti terlihat pada Tabel dibawah ini: 
Tabel 4

Hasil Pengujian Validitas Variabel Keadilan Distributif

\begin{tabular}{|l|c|c|c|}
\hline \multicolumn{1}{|c|}{ Item Pertanyaan } & Koefisien Factor loading & Standar & Kesimpulan \\
\hline Interaksional_1 & 0.606 & $\geq 0,40$ & Valid \\
\hline Interaksional_2 & 0.591 & $\geq 0,40$ & Valid \\
\hline Interaksional_3 & 0.687 & $\geq 0,40$ & Valid \\
\hline Interaksional_4 & 0.754 & $\geq 0,40$ & Valid \\
\hline Interaksional_5 & 0.552 & $\geq 0,40$ & Valid \\
\hline Interaksional_6 & 0.598 & $\geq 0,40$ & Valid \\
\hline
\end{tabular}

Pada Tabel 4 terlihat bahwa seluruh item pertanyaan yang digunakan dalam mengukur keadilan interaksional valid. Masing masing item pertanyaan yang valid memiliki koefisien factor loading diatas atau sama dengan 0,40. Didalam tahapan pengujian tidak satu pun item pertanyaan yang di eliminasi karena tidak memenuhi syarat atau pun mengalami ambigu sehingga seluruh item pertanyaan yang valid dapat terus digunakan kedalam tahapan pengolahan data lebih lanjut.

\section{Hasil Pengujian Reliabilitas}

Berdasarkan hasil pengujian reliabilitas yang telah dilakukan diperoleh ringkasan hasil terlihat pada Tabel 5 dibawah ini:

\section{Tabel 5}

Hasil Reliabilitas Variabel Penelitian

\begin{tabular}{|l|c|c|c|}
\hline \multicolumn{1}{|c|}{ Item Pertanyaan } & Cronbach Alpha & Standar & Kesimpulan \\
\hline Kepuasan Kerja & 0.757 & $\geq 60$ & Reliable \\
\hline Keadilan Distributif & 0.753 & $\geq 60$ & Reliable \\
\hline Keadilan Prosedural & 0.723 & $\geq 60$ & Reliable \\
\hline Keadilan Interaksional & 0.666 & $\geq 60$ & Reliable \\
\hline
\end{tabular}

Sumber: Olahan Data Sekunder: 2017

Pada Tabel terlihat bahwa seluruh variabel penelitian yang terdiri dari kepuasan kerja, keadilan distributif, keadilan prosedural dan keadilan interaksional telah memiliki nilai koefisien Cronbach Alpha diatas atau sama dengan 0,60 sehingga dapat disimpulkan bahwa seluruh variabel penelitian yang digunakan didalam penelitian ini telah memiliki tingkat kehandalan yang baik, sehingga tahapan pengolahan data lebih lanjut dapat segera dilakukan.

\section{Pengujian Asumsi Klasik}

Berdasarkan tahapan pengujian yang telah dilakukan diperoleh ringkasan hasil pengujian terlihat pada sub bab dibawah ini:

\section{Hasil Pengujian Normalitas}

Berdasarkan hasil pengujian normalitas yang telah dilakukan diperoleh ringkasan hasil terlihat pada Tabel dibawah ini:

\section{Tabel 6}

Hasil Pengujian Normalitas Residual

\begin{tabular}{|c|c|c|c|}
\hline Keterangan & Asymp Sig (2-Tailed) & Cut Off & Kesimpulan \\
\hline Absolute Residual & 0,782 & 0,05 & Normal \\
\hline
\end{tabular}

Sumber: Olahan Data Sekunder: 2017 
Sesuai dengan Tabel terlihat bahwa nilai absolute residual yang mewakili seluruh variabel penelitian telah memiliki nilai asymp sig (2-tailed) diatas atau sama dengan 0,05 sehingga dapat disimpulkan bahwa seluruh variabel penelitian yang akan dibentuk kedalam sebuah model regresi berganda telah berdistribusi normal sehingga tahapan pengolahan data lebih lanjut dapat segera dilakukan.

\section{Hasil Pengujian Multikolinearitas}

Pengujian multikolinearitas dilakukan dengan menggunakan tolerance dan Variance Influence Factor (VIF). Berdasarkan hasil pengujian yang telah dilakukan diperoleh ringkasan hasil terlihat pada Tabel 7 dibawah ini:

\section{Tabel 7}

Hasil Pengujian Multikolinearitas

\begin{tabular}{|l|c|c|c|}
\hline \multicolumn{1}{|c|}{ Variabel Independen } & Tolerance & VIF & Kesimpulan \\
\hline Keadilan Distributif & 0.955 & 1.047 & Tidak Terjadi \\
\hline Keadilan Prosedural & 0.980 & 1.000 & Tidak Terjadi \\
\hline Keadilan Interaksional & 0.956 & 1.046 & Tidak Terjadi \\
\hline
\end{tabular}

Sumber: Olahan Data Sekunder: 2017

Berdasarkan hasil pengujian mulitikolinearitas terlihat bahwa masing masing variabel independen yang terdiri dari keadilan distributif, keadilan prosedural dan keadilan interaksional telah memiliki nilai tolerance diatas 0,10 sedangkan nilai VIF telah berada dibawah 10 sehingga dapat disimpulkan bahwa masing masing variabel independen yang akan dibentuk kedalam sebuah model regresi berganda telah terbebas dari gejala multikolinearitas, sehingga tahapan pengolahan data lebih lanjut dapat segera dilanjutkan.

\section{Hasil Pengujian Heteroskedastisitas (Glejser)}

Pengujian heteroskedastisitas dilakukan dengan menggunakan uji Glejser. Berdasarkan hasil pengujian heteroskedastisitas yang telah dilakukan diperoleh ringkasan hasil terlihat pada Tabel dibawah ini:

\section{Tabel 8}

Hasil Pengujian Heteroskedastisitas

\begin{tabular}{|l|c|c|c|}
\hline \multicolumn{1}{|c|}{ Variabel Independen } & Sig & Alpha & Kesimpulan \\
\hline Keadilan Distributif & 0,695 & $\geq 0,05$ & Tidak Terjadi \\
\hline Keadilan Prosedural & 0,881 & $\geq 0,05$ & Tidak Terjadi \\
\hline Keadilan Interaksional & 0,262 & $\geq 0,05$ & Tidak Terjadi \\
\hline
\end{tabular}

Sumber: Olahan Data Sekunder: 2017

Berdasarkan hasil pengujian heteroskedastisitas terlihat bahwa masing masing variabel variabel independen yang terdiri dari keadilan distributif, keadilan prosedural dan keadilan interaksional telah memiliki nilai sig diatas atau sama dengan 0,05 sehingga dapat disimpulkan bahwa seluruh variabel independen yang telah diregresikan dengan nilai absolute residual telah terbebas dari gejala heteroskedastisitas sehingga tahapan pengolahan data lebih lanjut dapat segera dilakukan.

\section{Pengujian Hipotesis}

Setelah seluruh variabel penelitian yang digunakan berdistribusi normal, dan terbebas dari seluruh gejala asumsi klasik maka tahapan pengujian statistik 
dapat dilaksanakan. Secara umum tahapan pengujian hipotesis yang dilakukan meliputi:

\section{Analisis Koefisien Determinasi}

Berdasarkan hasil pengujian yang telah dilakukan diperoleh ringkasan terlihat pada Tabel dibawah ini:

\section{Tabel 9}

Hasil Pengujian R-square

\begin{tabular}{|l|r|r|r|r|}
\hline Model & $R$ & $R$ Square & $\begin{array}{c}\text { Adjusted } \\
\text { R Square }\end{array}$ & $\begin{array}{c}\text { Std. Error of } \\
\text { the Est imate }\end{array}$ \\
\hline 1 & $.330^{a}$ & .509 & .486 & 4.391 \\
\hline
\end{tabular}

a. Predictors: (Constant), Keadilan Interaksional, Keadilan Prosedural, Keadilan Distributif

Sumber: Olahan Data Sekunder: 2017

Pada Tabel terlihat bahwa nilai koefisien determinasi yang dihasilkan adalah sebesar 0,509 hasil yang diperoleh menunjukan bahwa keadilan distributif, keadilan prosedural dan keadilan interaksional mampu memberikan variasi kontribusi dalam mempengaruhi kepuasan karyawan Bank Nagari Cabang Utama Padang sebesar 50,90\% sedangkan sisanya 49,10\% lagi dijelaskan oleh variabel lain yang tidak digunakan dalam penelitian ini seperti budaya organisasi, gaya kepemimpinan, semangat kerja dan sebagainya.

\section{Hasil Pengujian F-statistik}

Pengujian F-statistik bertujuan untuk mengetahui pengaruh variabel independen terhadap variabel dependen secara bersama sama. Sesuai dengan hasil pengolahan data yang telah dilakukan diperoleh ringkasan hasil terlihat pada Tabel dibawah ini:

Tabel 10

\section{Hasil Pengujian F-statistik}

\begin{tabular}{|c|c|c|c|c|c|c|}
\hline \multicolumn{7}{|c|}{ ANOVAB } \\
\hline Model & & $\begin{array}{l}\text { Sum of } \\
\text { Squares }\end{array}$ & df & Mean Square & $\mathrm{F}$ & Siq. \\
\hline & $\begin{array}{l}\text { Regression } \\
\text { Residual } \\
\text { Total }\end{array}$ & $\begin{array}{r}279.991 \\
2294.805 \\
2574.797\end{array}$ & $\begin{array}{r}3 \\
119 \\
122\end{array}$ & $\begin{array}{r}93.330 \\
19.284\end{array}$ & 4.840 & $.003^{a}$ \\
\hline
\end{tabular}

a. Predictors: (Constant), Keadilan Interaksional, Keadilan Prosedural, Keadilan Dist ribut if

b. Dependent Variable: Kepuasan Kerja

Sumber: Olahan Data Sekunder: 2017

Berdasarkan hasil pengujian F-statistik juga diperoleh nilai sig sebesar 0,003. Didalam tahapan pengujian digunakan tingkat kesalahan sebesar 0,05. Hasil yang diperoleh menunjukan bahwa nilai sig sebesar $0,003<$ alpha 0,05 maka keputusannya adalah Ho ditolak dan Ha diterima sehingga dapat disimpulkan bahwa keadilan distributif, keadilan prosedural dan keadilan interaksional secara bersama sama berpengaruh terhadap kepuasan kerja karyawan Bank Nagari Cabang Utama Padang. Hasil yang diperoleh juga mengisyaratkan variabel independen yang digunakan untuk memprediksi peningkatan kepuasan kerja pegawai adalah tepat, oleh sebab itu tahapan pengujian hipotesis dapat segera dilanjutkan. 


\section{Hasil Pengujian t-statistik}

Pengujian t-statistik bertujuan untuk membuktikan secara empiris pengaruh variabel independen terhadap variabel dependen secara individual. Berdasarkan hasil pengujian yang telah dilakukan diperoleh ringkasan hasil terlihat pada Tabel dibawah ini:

\section{Tabel 11}

\section{Hasil Pengujian Hipotesis}

\begin{tabular}{|ll|r|r|r|r|r|}
\hline \multirow{2}{*}{ Model } & \multicolumn{2}{|c|}{$\begin{array}{c}\text { Unstandardized } \\
\text { Coeff icients }\end{array}$} & $\begin{array}{c}\text { Standardized } \\
\text { Coeff icients }\end{array}$ & & \\
\cline { 3 - 7 } & & \multicolumn{1}{|c|}{ B } & Std. Error & Beta & \multicolumn{1}{c|}{ Sig. } \\
\hline 1 & (Constant) & 38.230 & 4.478 & .537 & .000 \\
& Keadilan Distributif & .471 & .206 & .073 & 2.829 & .009 \\
& Keadilan Prosedural & .550 & .164 & .290 & 3.353 & .001 \\
& Keadilan Interaksional & -.159 & .112 & -.126 & -1.424 & .157 \\
\hline
\end{tabular}

a. Dependent Variable: Kepuasan Kerja

Sumber: Olahan Data Sekunder: 2017

Pada tahapan pengujian hipotesis pertama yang diuji dengan menggunakan uji t-statistik diperoleh nilai sig sebesar 0,009. Pada tahapan pengolahan data digunakan tingkat kesalahan sebesar 0,05 Hasil yang diperoleh didalam tahapan pengujian statistik menunjukan bahwa nilai sig sebesar $0,009<$ alpha 0,05 maka keputusannya adalah Ho ditolak dan Ha diterima sehingga dapat disimpulkan bahwa keadilan distributif berpengaruh terhadap kepuasan kerja karyawan Bank Nagari Cabang Utama Padang.

Pada tahapan pengujian hipotesis kedua yang bertujuan untuk membuktikan pengaruh keadilan prosedural terhadap kepuasan kerja pegawai Bank Nagari Cabang Utama, diperoleh nilai sig sebesar 0,009. Didalam tahapan pengujian digunakan tingkat kesalahan sebesar 0,05. Hasil yang diperoleh menunjukan bahwa nilai sig sebesar $0,009<$ alpha 0,05 maka keputusannya adalah Ho ditolak dan Ha diterima sehingga dapat disimpulkan bahwa keadilan prosedural berpengaruh terhadap kepuasan kerja karyawan Bank Nagari Cabang Utama Padang.

Sesuai dengan hasil pengujian hipotesis ketiga yang bertujuan untuk membuktikan pengaruh keadilan interaksional terhadap kepuasan kerja karyawan Bank Nagari Cabang Utama Padang, diperoleh nilai sig sebesar 0.157. Pada tahapan pengolahan data digunakan tingkat kesalahan sebesar 0,05. Hasil yang diperoleh menunjukan bahwa nilai sig sebesar 0.157 berada diatas 0,05. Maka dapat disimpulkan bahwa keadilan interaksional tidak berpengaruh signifikan terhadap kepuasan kerja karyawan Bank Nagari Cabang Utama Padang.

\section{PEMBAHASAN}

\section{Pengaruh Keadilan Prosedural Terhadap Kepuasan Karyawan Bank Nagari Cabang Utama Padang.}

Berdasarkan hasil pengujian hipotesis pertama ditemukan bahwa keadilan prosedural berpengaruh positif terhadap kepuasan karyawan Bank Nagari Cabang Utama Padang. Hasil penelitian Krisnayanti dan Riana (2015) menemukan bahwa keadilan distributif berpengaruh positif terhadap kepuasan kerja. Peningkatan tingkat keadilan distributive dapat diamati dari distribusi jabatan, distribusi kompensasi hingga distribusi wewenang di dalam organisasi. Semakin adil distribusi yang dirasakan pegawai akan semakin meningkatkan nilai kepuasan 
dalam bekerja. Kristanto (2013) menemukan bahwa keadilan organisasi yang diukur dengan keadilan distributive berpengaruh positif terhadap kepuasan kerja pegawai. Penelitian yang dilakukan oleh Stephen dan Schappe (1998) menemukan keadilan organisasional yang diukur dengan keadilan distributif berpengaruh positif terhadap kepuasan pegawai dalam bekerja. Hasil yang diperoleh dapat dimaknai bahwa semakin tinggi tingkat keadilan distributive yang dirasakan pegawai seperti tingkat partisipasi dalam organisasi dalam bentuk pemberian kepangkatan, wewenang dan gaji, akan mendorong muncul rasa nyama dan kepuasan dalam diri pegawai.

\section{Pengaruh Keadilan Distributif Terhadap Kepuasan Karyawan Bank Nagari} Cabang Utama Padang.

Berdasarkan hasil pengujian hipotesis yang telakukan ditemukan bahwa keadilan distributif berpengaruh positif terhadap kepuasan kerja yang dirasakan karyawan Bank Nagari Cabang Utama Padang. Hasil yang diperoleh pada tahapan pengujian hipotesis kedua sejalan dengan penelitian Krisnayanti dan Riana (2015) mengungkapkan bahwa keadilan organisasional yang diukur dengan keadilan procedural berpengaruh terhadap kepuasan kerja yang dirasakan pegawai, makna yang tersirat didalam hasil penelitian tersebut menunjukan bahwa semakin tinggi tingkat keadilan procedural yang dirasakan pegawai. Kristanto (2013) ditemukan bahwa keadilan procedural berpengaruh positif terhadap kepuasan kerja pegawai. hingga kenaikan pangkat kepada

\section{Pengaruh Keadilan Interaksional Terhadap Kepuasan Karyawan Bank Nagari Cabang Utama Padang.}

Berdasarkan hasil pengujian hipotesis ketiga ditemukan bahwa keadilan interaksional tidak berpengaruh signifikan terhadap kepuasan karyawan Bank Nagari Cabang Utama Padang. Temuan yang diperoleh pada tahapan pengujian hipotesis ketiga tidak sejalan dengan hasil penelitian Krisnayanti dan Riana (2015) menemukan bahwa keadilan interaksional berpengaruh positif terhadap kepuasan kerja pegawai. Kristanto (2013) menemukan bahwa keadilan interaksional berpengaruh positif terhadap kepuasan kerja yang dirasakan pegawai. Stephen dan Schappe (1998) menemukan bahwa keadilan interaksiobak berpengaruh positif terhadap kepuasan kerja pegawai, hasil yang diperoleh dapat dimaknai ketika tingkat keadilan interaksional terus meningkat didalam organisasi maka kepuasan kerja yang dirasakan pegawai dalam bekerja akan meningkat. Terjaganya keadilan interaksional telah mendorong suasana yang kondusif dalam bekerja sehigga mendorong meningkatnya kepuasan kerja yang dirasakan pegawai.

\section{SIMPULAN}

Sesuai dengan analisis dan pembahasan hasil pengujian hipotesis yang telah dilakukan maka dapat diajukan beberapa kesimpula penting yang merupakan jawaban dari permasalahan yang diajukan dalam penelitian ini yaitu:

1. Keadilan distributif berpengaruh positif terhadap kepuasan kerja karyawan Bank Nagari Cabang Utama Padang.

2. Keadilan prosedural berpengaruh positif terhadap kepuasan kerja karyawan Bank Nagari Cabang Utama Padang. 
3. keadilan interaksional tidak berpengaruh terhadap kepuasan kerja karyawan Bank Nagari Cabang Utama Padang.

\section{DAFTAR PUSTAKA}

Ahmadi Awaludin, Deddy TT dan M Thahir. 2011. Hubungan Kepuasan Kerja dengan Komitmen Organisasi Pegawai Dinas Tatuang dan Bangunan Desa Makasar. Jurnal Ilmu Administrasi dan Organisasi Volume 17 No 1 Januari - April 2010 Page 43 - 51

Aldi, Y., \& Susanti, F. (2019). Pengaruh Stress Kerja Dan Motivasi Kerja Terhadap Prestasi Kerja Karyawan Pada PT. Frisian Flag Indonesia Wilayah Padang. https://doi.org/10.31227/osf.io/et4rn

Arikunto Suharsimi. 2010. Metodologi Penelitian Untuk Ilmu Sosial. Gramedia Pustaka, Jakarta.

Colquitt A Jason. 2012. Organizational Justice. Handbooks Online of Organizational Psychology Volume 1 July 2012.

Cropanzano Russell, Bowen David E dan Stephen W Gilliland. 2007.The Management of Organizational Justice. Articles Academy of Management Perspective November 2007/

Davis, Keith dan Newstrom, John W. 2004. Perilaku dalam Organisasi. Edisi 7 Bahasa Indonesia. Jilid 1. Jakarta: Penerbit Erlangga.

Fendi, Z., \& Susanti, F. (2018). Pengaruh Kepuasan Kerja Terhadap Turnover Intention Dengan Komitmen Organisasi Sebagai Variabel Intervening Pada CV. Belibis Pariaman. https://doi.org/10.31227/osf.io/wumgx

Ghozali, Imam. 2013. Aplikasi Analisis Multivariate dengan Program IBM SPSS 21, Edisi 5. Semarang: Badan Penerbit Universitas Diponegoro

Gibson L James, John M Ivancevich, James H Donellydan Robert Konopaske. 2009. Organizations Behavior Structure Processes Fourteenth Edition. McGraw-Hill, Irwin.

Hair Jr Joseph, William C Black, Barry J Babin dan Rolph F Anderson. 2010. Multivariate Data Analysis. Mc Graw-Hill, Irwin.

Junaidi, R., \& Susanti, F. (2019). Pengaruh Gaya Kepemimpinan Dan Budaya Organisasi Terhadap Kinerja Pegawai Pada UPTD Baltekkomdik Dinas Pendidikan Provinsi Sumatera Barat. https://doi.org/10.31227/osf.io/bzq75 
Krisnayanti Gusti Ayu dan Riana I Gende. 2015. Pengaruh Keadilan Organisasional Terhadap Kepuasan Kerja Karyawan. E-Jurnal Manajemen Unud Volume 4 Nomor 9 Universitas Udayana, Bali.

Kristanto Sentot. 2013. Pengaruh Keadilan Organisasional Terhadap Kepuasan Kerja dan Dampaknya Terhadap Komitmen dan Intensi Keluar di PT Indonesia Power UBP Bali. Tesis Universitas Udayana, Bali.

Kenneth J, Harris Martha C Andrews dan K Michael Kacmar. 2007. The Moderating Effects of Justice on the Relationship Between Organizational Politics and Workplace Attitude. Journal Business Psychology Page 135 144.

Lubis, A. Y. O., \& Susanti, F. (2019). Pengaruh Gaya Kepemimpinan Dan Kompensasi Terhadap Prestasi Kerja Karyawan (Studi pada PT Japfa Comfeed Indonesia (JCI) Tbk Devisi Fam 1. https://doi.org/10.31227/osf.io/7tbrg

Luthans, Fred. 2010. Organization Behavior12 ${ }^{\text {th }}$ Edition, McGraw-Hill, International Edition.

Mas'ud Fuad. 2004. Survey Diagnosi Organisasional Konsepdan Aplikasi. Semarang. Badan Penerbit Universitas Dipenegoro.

Mangkunegara, A Prabu, Anwar. 2013. Sumber Daya Manusia Perusahaan, Cetakan Kesebelas. Remaja Rosdakarya. Bandung.

Margono. 2010. Metodologi Penelitian Pendidikan. Jakarta: Rineka Cipta.

Mayliza, R. (2019). Pengaruh Konflik Dan Kejenuhan Terhadap Kepuasan Kerja Karyawan PT. PLN (Persero) Sektor Pembangkitan Dan Pengendalian Pembangkitan Ombilin. https://doi.org/10.17605/OSF.IO/DQZ3K

Robbins Stephen P, Timothy Judge. 2012. Organizational Behavior 15 Edition. McGraw-Hill, Irwin.

Ridho, M., \& Susanti, F. (2019). Pengaruh Stres Kerja Dan Motivasi Kerja Terhadap Kepuasan Kerja Pada Karyawan Bank Mandiri Syariah Cabang Padang. https://doi.org/10.31227/osf.io/pa2cg

Rivai, Veithzal. 2004. Manajemen Sumber Daya Manusia Untuk Perusahaan: Dari Teori Ke Praktik. Raja Grafindo Persada, Jakarta

Sekaran Uma. 2013. Metodologi Penelitian Bisnis. Edisi Indonesia, Erlangga, Jakarta. 
Stephen P dan Schappe. 1998. Understanding Employee Job Satisfaction: The Importance of Procedural and Distributive Justice. Journal of Business and Psychology Volume 12 No 4 Summer 1998.

Sugiono. 2007. Metodologi Penelitian. Salemba Empat, Jakarta.

Sudjana. 2005. Metode Statistika Edisi Ke-6. Tarsito, Bandung

Tang L and Sarfield Baldwin. 1996. Distributive and Prosedural Justice as Related to Satisfaction and Commitment SAM Advance Management Journal Vol 61 No 3 pp 25-31

Tjahjono, She Hwei dan Elisabeth Cintya Santosa. 2015. Penaruh Keadilan Prosedural dan Keadilan Distributif Terhadap Komitmen Organisasi. Jurnal Dinamika Ekonomi dan Bisnis Volume 9 Nomor 2 Oktober 2015.

Wibowo. 2013. Perilaku Dalam Organisasi. Edisi Kedua. Jakarta: Rajawali Pers.

Yudistira, D. S., \& Susanti, F. (2019). Pengaruh Motivasi Kerja Dan Budaya Kerja Terhadap Kinerja Karyawan Dinas Pemberdayaan Masyarakat Dan Desa, Pengendalian Penduduk Dan Keluarga Berencana Kabupaten Pesisir Selatan. https://doi.org/10.31227/osf.io/jk54m 